DOI https://doi.org/10.30525/978-9934-26-004-9-123

\title{
МУЗИЧНІ СЮЖЕТИ В СКУЛЬПТУРНІЙ ОЗДОБІ АРХІТЕКТУРИ ЛЬВОВА КІНЦЯ ХІХ - ПОЧАТКУ ХХ СТ.
}

\author{
Великанич С. P. \\ аспірантка кафедри історії та теорї культури \\ Начіональної музичної академї Украӥни імені П. І. Чайковського \\ м. Київ, Украӥна
}

В процесі дослідження музичної іконографії в декорі архітектурних споруд у Львові в період кінця XIX - початку XX ст. було виявлено велику кількість сюжетних зразків, розшифрування яких $є$ не лише цікавим культурологічним квестом, але й цінним науковим джерелом в розкритті нових культурно-історичних фактів.

Ця вагома (як по кількості, так і по наповненню) група зразків містить приклади як міфологічних замальовок, прочитання яких потребує знання контексту історично віддаленого періоду, так і складних еклектичних композицій, інтерпретація яких повинна передбачати врахування ряду науково-методологічних факторів.

Одним із зразків шаблонного характеру є мотив, який зустрічається доволі часто у різних частинах міста. Скульптурна сценка за участю путті $^{1}$ по вул. Клепарівській, 17-19, оскільки цей сюжетний зразок $\epsilon$ доволі популярним і зустрічається ще за кількома адресами.

Сюжет, який спостерігаємо на даному зразку зображає трьох путті: перший 3 них тримає келих з вином в одній руці і капелюх з плюмажем ${ }^{2}$ в іншій; другий - по центру - стоїть 3 кифарою; третій - за роялем початку XX ст. Всі троє одягнені у тогу, одяг древніх римлян.

В одному зображенні зібрані елементи різних епох i, здавалося б, непоєднувані речі, проте образ загалом виглядає цілком органічно i, як виявилось, був доволі популярним серед архітекторів або ж замовників того часу. Цей же мотив зустрічаємо по вул. Зеленій, Тарнавського, Підзамче, Пильникарській.

Композиційно, зображення досконало вписане в прямокутне панно, яке розділяє поверхи споруди і без детального заглиблення у його аналіз не викликає жодних протиріч, однак, важливим $є$ замислитись над

${ }^{1}$ Путті - художній образ маленьких дітей з крилами, популярний в ренесансному і класичному мистецтві.

2 Від франц. plumage «оперення» - оздоба 3 пір'я на чоловічому головному уборі. 
причиною популярності цього сюжету. Вона може бути як цілком банальною - штамп, який відтворити дешевше, ніж створювати новий, так і вимогою часу. Стильове різноманіття органічно вписувалось в архітектурну концепцію міста на зламі віків.

Другий сюжет, який хотілося б проаналізувати окремо знаходимо на будівлі по вул. Коциловського, 15 a, збудованій в 1911 р. за проектом Г. Заремби. В даному випадку мова йде вже не про шаблонність, а про індивідуальний авторський вияв. Скульптурну оздобу було доручено виконати Т. Блотницькому. Вона являє собою п'ять алегоричних барельєфів, які зображають етапи еволюції людства [1, с. 104].

Тут ми знову зустрічаємо досить еклектичну сюжетну історію, яка провокує детальніше заглибитись в їі суть. Скульптурні групи наділені назвами: «Прометей» та «Музи», «Давні цивілізації» (Єгипет, Греція, Римська імперія), «Праця і мистецтво», «Транспорт» [4]. I, хоч автор ніби прямо вказує на суть зображеного, однак реалізація цієї суті виглядає цілком не банально.

Наступним зразком, який демонструє стильове різноманіття в архітектурі Львова на межі століть є будинок по вул. Городоцькій, 117, збудований в 1911 році за проектом Г. Орлеана та Е. Скавінського. Стиль споруди мистецтвознавці визначають як неоромансько-неомавританський, який реалізовано не в останню чергу завдяки скульптурній оздобі 3. Курчинського, адже саме ліпнина створює неповторний вигляд фасаду в такому оригінальному ключі [2].

Стильовим каталізатором в даному випадку є орнаментальні мотиви, присутні в металевих конструкціях (балконних огорожах та брамі), а також обрамлюють віконні отвори. Зразки музичної іконографії представлені у підвіконних тафлях, розміщених між поверхами - це маленькі путті, один з яких грає на музичному інструментів, схожому на гітару (інструмент характерний для мавританської культури), інший - на флейті Пана. Фігури не вписуються у рамки, за рахунок чого «оживають» і створюється ілюзію руху.

Наступним, вартим уваги сюжетним зразком є будинок по вул. Князя Романа, 32. Він продовжує лінію сценок із маленькими путті, вже знайомим і популярним мотивом в архітектурі Львова. Неокласична споруда, збудована в 1911 році за проєктом Л. Теуша [2]. Станом на сьогодні споруда одним боком прилягає до Львівської національної музичної академії ім. М. Лисенка, а також знаходиться навпроти Коледжу культури і мистецтв, а в самій будівлі знаходиться мистецька філія міської дитячої бібліотеки. Попри явну музичну атмосферу місця, нашим завданням все ж $є$ розшифрування значення i походження сюжету, що бачимо на скульптурному зображенні.

Отже, на даній будівлі маємо два типи панно, які почергово повторюються, однак очевидним є той факт, що їх об'єднують дві теми наука i мистецтво. Свідченням цього $\epsilon$ атрибути, які бачимо на 210 
зображенні: глобус, смолоскип, книга, флейта Пана. Предмети володіють символічним значенням і їхня поява на будівлі однозначно мала на меті викликати образні асоціації.

Ще однією цікавою та естетично довершеною $є$ сюжетна сценка на фасаді споруди по вул. Пильникарській, 4. Сьогодні, це багатоквартирний житловий будинок. Оскільки даних про нього обмаль, виділимо те, що можемо виокремити із зображення. Як у попередньому зразку, на двох типах панно зображені путті, які в одному випадку представлені у вигляді будівельників, а в іншому - музикантів. В кожному 3 варіантів задіяно по чотири персонажі. Якщо у попередньому прикладі поєднувались наука і культура, то тут на одному будинку уживаються доволі полярні сфери.

Музичні сюжети в оздобі архітектурних споруд у Львові на зламі XIX - XX ст. демонструють широке різноманіття образів і тем, а їх детальне дослідження здатне розкрити цікаві і невідомі факти культурної історії міста.

\title{
Література:
}

1. Бірюльов Ю. Мистецтво Львівської сецесії. - Львів: Центр Європи, 2005. - 184 с.

2. Вулиці Львова. URL: https://streets.lvivcenter.org/uk/

3. Николишин Ю. Путівник по Львову. - Львів: Апріорі, 2016. - 96 с.

4. Студницька М. Синтез мистецтв у громадській i житловій apхітектурі Галичини першої третини XX ст. URL: http://um.etnolog.org.ua/zmist/2014/158.pdf.

DOI https://doi.org/10.30525/978-9934-26-004-9-124

\section{ДОСЛІДЖЕННЯ СУЧАСНОГО МУЗИЧНОГО МИСТЕЦТВА В АСПЕКТІ «ПАМ'ЯТІ КУЛЬТУРИ»: ДОСВІД КУЛЬТУРОЛОГІЇ}

\author{
Гармель О. В. \\ кандидат мистеитвознавства, доцент, \\ дочент кафедри теорії музики \\ Київської муніщипальної академії музики імені Р. М. Глієра \\ м. Київ, Украӥна
}

Пошук методологічних орієнтирів для дослідження сучасного музичного мистецтва $є$ однією з актуальних проблем мистецтвознавства. Особливого значення це набуває при аналітичному зануренні у твори, в яких композитори на етапі формування задуму свідомо залучають досвід 